\title{
Induction of Root Development and Apical Closure in Permanent Mandibular Molar with Irreversible Pulpitis through Total Pulpotomy with Application of Mineral Trioxide Aggregate
}

\author{
Inducción del Termino de Desarrollo Radicular y Cierre Apical en Molar Mandibular \\ Permanente con Pulpitis Irreversible a Través de Pulpotomía Total con Aplicación \\ de Agregado de Trióxido Mineral
}

Felipe Gomez; Jorge Fuentes²; Diego Saravia³ \& Mónica Silva ${ }^{4}$

GOMEZ, F.; FUENTES, J.; SARAVIA, D. \& SILVA, M. Induction of root development and apical closure in permanent mandibular molar with irreversible pulpitis through total pulpotomy with application of mineral trioxide aggregate. Int. J. Odontostomat., 14(2):144-149, 2020.

SUMMARY: Loss of teeth vitality when root formation is incomplete, results in weaker structures leaving them prone to fractures and unfavourable long-term prognosis. Apexogenesis is currently the treatment of choice in immature teeth and is indicated in vital teeth without pulpal pathologies. The treatment aims to eliminate the causal agent of the damage, and provide the necessary conditions to preserve vitality in the tooth and induce apical root closure. A 6-year-old male patient was treated at the Endodontics Clinic, Universidad de La Frontera upon complaining of acute pain in tooth 30 . The tooth presented incomplete root development due to dental caries with pulp exposure and a diagnosis of irreversible symptomatic pulpitis. Total pulpotomy was performed with the application of Mineral Trioxide Aggregate and controlled at 1, 4, 6, 7 and 12 months, achieving root development and apical closure in the permanent molar. The result was comparable with studies that support this therapy in teeth with irreversible pulpitis. This work seeks to contribute to the existing evidence on the management of immature permanent teeth with irreversible pulpitis to induce root development and apical closure, and maintain pulp vitality.

KEY WORDS: apexogenesis, pulpotomy, mineral trioxide aggregate.

\section{INTRODUCTION}

Histologically, the pulp-dentin complex is composed of odontoblasts that synthesize dentin, numerous fibroblasts, undifferentiated mesenchymal cells, an extracellular matrix rich in Type I and II collagen arranged randomly, an amorphous substance composed of glycoproteins and proteoglycans, and numerous blood vessels and nerve fibres that enter through the root apex (Dhillon et al., 2016).

These types of tissue, as well as enamel, dentin, cement, periodontal ligament and alveolar bone tissue, originate during odontogenesis, a process that involves histogenesis, histodifferentiation, morph differentiation and apposition (American Association of Endodontists, 2016), allowing the teeth to develop and acquire their shape and function within the oral-craniofacial system. However, these processes may be interrupted or modified by factors such as trauma, dental caries or pulpal exposure by accident, and in the long term, injuries and subsequent pulpal pathologies may be responsible for stopping radicular formation and apical closure (Nagata et al., 2014).

\footnotetext{
${ }^{1}$ Especialidad de Endodoncia, Facultad de Odontología, Universidad de La Frontera, Temuco, Chile.

${ }^{2}$ Departamento de Odontología Integral Adultos, Facultad de Odontología, Universidad de La Frontera, Temuco, Chile.

${ }^{3}$ Departamento de Odontopediatría y Ortodoncia, Facultad de Odontología, Universidad de La Frontera, Temuco, Chile.

${ }^{4}$ Escuela de Odontología, Facultad de Odontología, Universidad de La Frontera, Temuco, Chile.

Funded by Universidad de La Frontera, Project DIUFRO Nº DI15-0074
} 
Existing treatments for teeth of this type with pulp vitality and without pulp pathology aim to eliminate the causal agent of the damage and provide the tooth with the necessary conditions and stimuli to preserve vitality (Ghoddusi et al., 2014) and favour root formation with posterior apical closure (Qudeimat et al., 2017), known as apexogenesis (Holland et al., 2008).

A well-known procedure for apexogenesis is Total Pulpotomy with the application of Mineral Trioxide Aggregate (MTA) as an inducer of differentiation (Qudeimat et al., 2007). This involves surgical removal of the cameral dental pulp and subsequent application of MTA to preserve the vitality of the root pulp (American Association of Endodontists). It has proved to be a reliable treatment in immature permanent teeth without pulp pathology, replacing the pulpectomy and apexification therapies (Nosrat et al., 2013) which produced weakened teeth prone to fractures (Cvek, 1992; Camp, 2008) and with unfavourable long-term prognosis (Rabie et al., 1986; Katebzadeh et al., 1998; Robertson et al., 2000).

The aim of this work was to show the evolution of a patient who underwent total pulpotomy therapy with MTA application in an immature permanent mandibular molar with irreversible pulpitis and pulp exposure due to caries.

\section{MATERIAL AND METHOD}

A 6-year-old male patient and his parents attended the endodontic clinic at Universidad de La Frontera in Temuco, Chile, consulting for acute pain in tooth 30 . On clinical and radiographic examination, a deep occlusal caries with pulpal exposure was observed (Figs. 1 and 2). In the cold sensitivity test, Endoice $₫$ Spray was applied with a cotton swab on the vestibular face of the tooth in the middle third of the crown, the patient reported intense, pungent, localized pain, evaluated at 7 on the visual analogue scale; pain disappeared after 40 seconds once the stimulus was removed. The patient did not report pain on vertical percussion. The diagnosis was irreversible symptomatic pulpitis in tooth 30 with incomplete root development and open apex.

Treatment options were evaluated. The treatment was explained to the parents and to the patient, obtaining their consent. Total pulpotomy with application of MTA was performed.
The therapy began with left inferior alveolar nerve block anaesthesia, using 1 tube $(1.8 \mathrm{~mL})$ of Lidocaine 1:100,000 with epinephrine constrictor vessel (Septodon®). The tooth was then isolated with a rubber dam and the tooth decay and affected hard tissues were eliminated using a round, high speed carbide bur. The cameral roof was removed and access preparation was carried out using a highspeed endo-zill bur (Fig. 3). The cameral pulp tissue was eliminated with a sterile Maillefer caries spoon, reaching the entrance of the root canals (Fig. 4). The tooth was irrigated profusely with saline. Haemostasis was achieved by applying a cotton sterile ball on the entrance of the root canals; bleeding was no longer observed after 5 minutes. Angelus ${ }^{\circledR}$ White MTA was prepared according to the manufacturer's instructions and $2 \mathrm{~mm}$ was applied over the entrance of the channels (Fig. 5). It was covered with a moistened cotton ball and the tooth was sealed with Ketac Molar $®$ conventional ionomer glass cement (Fig. 6). Occlusion was checked and the cement was polished with soflex ${ }^{\circledR}$ discs (3M ESPE) in black, blue and light blue.

Once the clinical procedure was completed, a periapical radiograph was taken to evaluate the MTA filling and the Coronary seal. After 7 days, the seal was renewed, again applying Ketac Molar ${ }^{\circledR}$ conventional ionomer glass cement.

Finally, clinical and radiographic controls were carried out at 1, 4, 7 and 12 months; on each occasion the first apical closure was observed radiographically (Figs. 7 to 10).

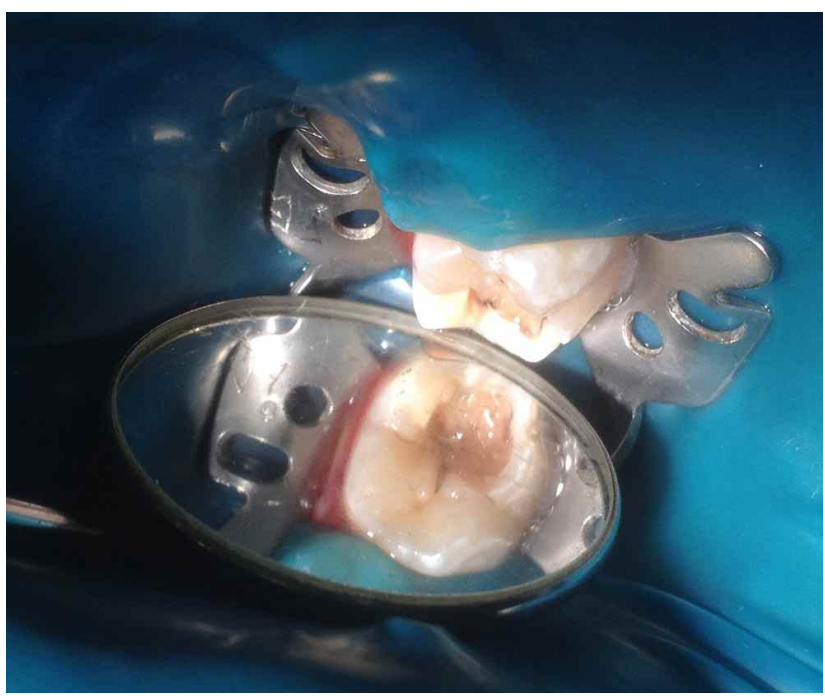

Fig. 1. Initial clinical view of tooth 30 , observing active occlusal caries of great extension. 
GOMEZ, F.; FUENTES, J.; SARAVIA, D. \& SILVA, M. Induction of root development and apical closure in permanent mandibular molar with irreversible pulpitis through total pulpotomy with application of mineral trioxide aggregate. Int. J. Odontostomat., 14(2):144-149, 2020

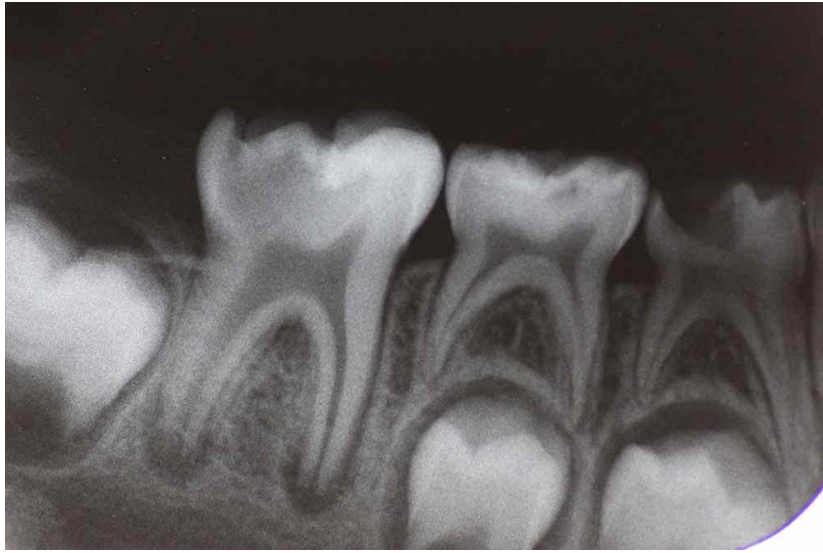

Fig. 2. Periapical retroalveolar radiograph tooth 30 . Projected caries lesion is observed in the pulp chamber.

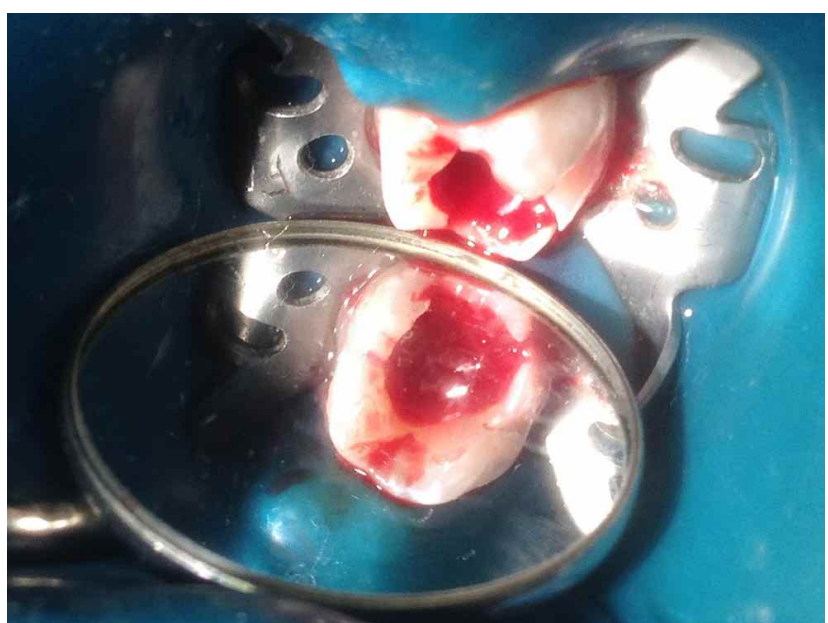

Fig. 3. Removal of the cameral roof. Abundant haemorrhage, sign of pulp vitality.

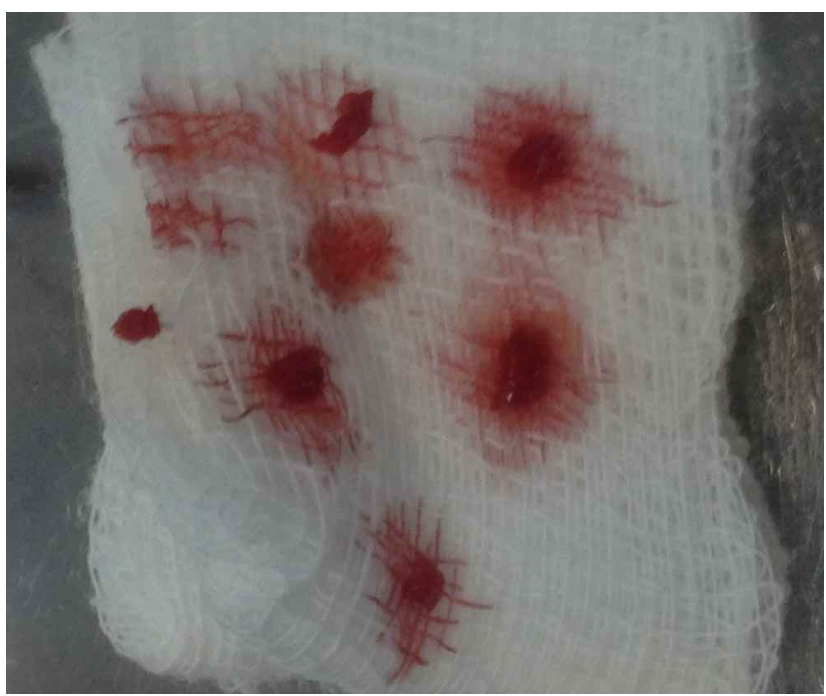

Fig. 4. View of remnants of cameral dental pulp removed with Maillefer® caries spoon and placed on sterile gauze on examination tray.

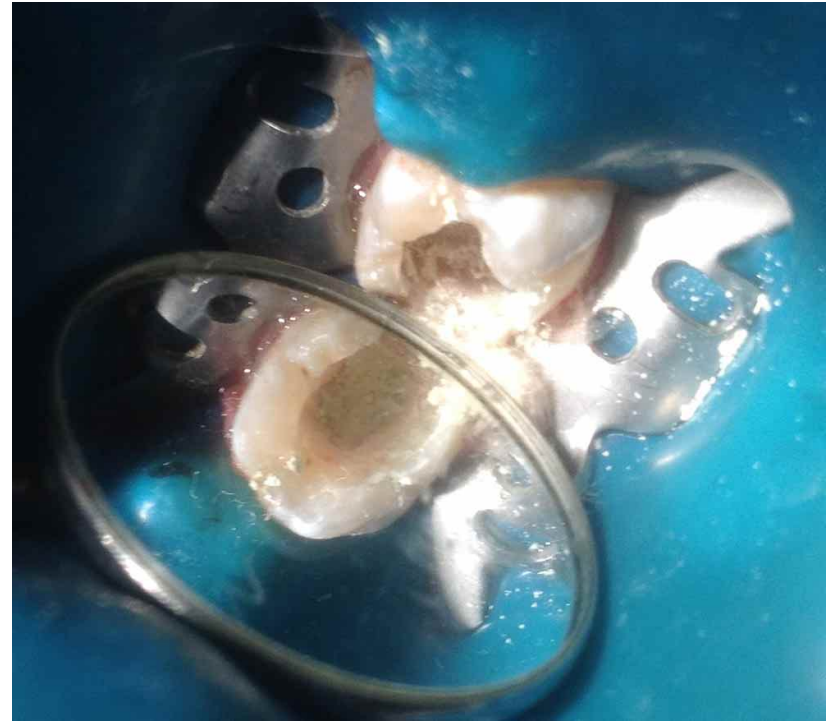

Fig. 5. Clinical view of application of $2 \mathrm{~mm}$ of white MTA mark Angelus $\circledR$ on the entrance of the root canals of tooth 30 .

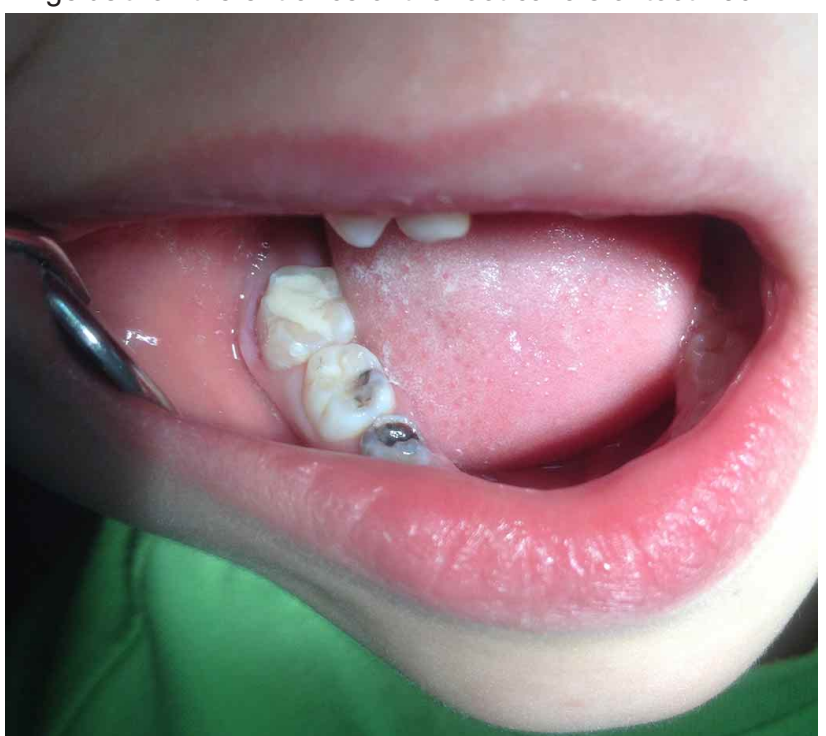

Fig. 6. Clinical view of temporary filling of tooth 4.6 with conventional ionomer glass Ketac Molar®.

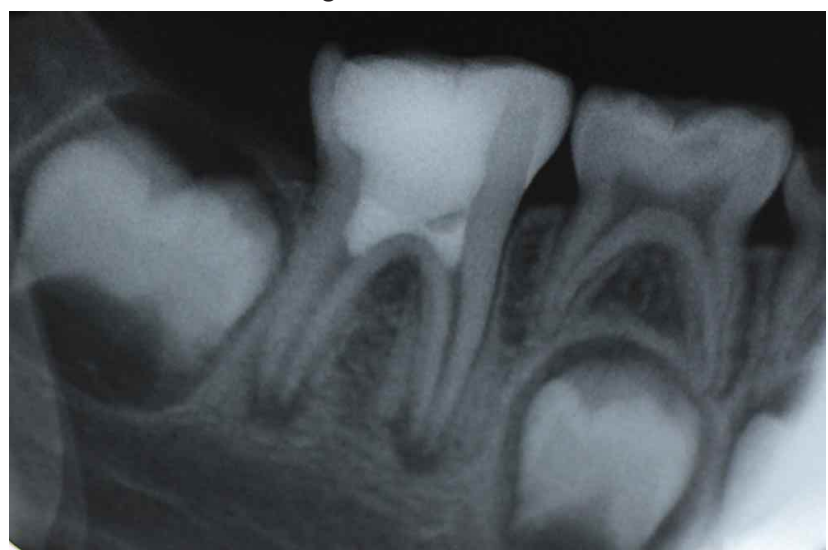

Fig. 7. X-ray at 1 month. 
GOMEZ, F.; FUENTES, J.; SARAVIA, D. \& SILVA, M. Induction of root development and apical closure in permanent mandibular molar with irreversible pulpitis through total pulpotomy with application of mineral trioxide aggregate. Int. J. Odontostomat., 14(2):144-149, 2020.

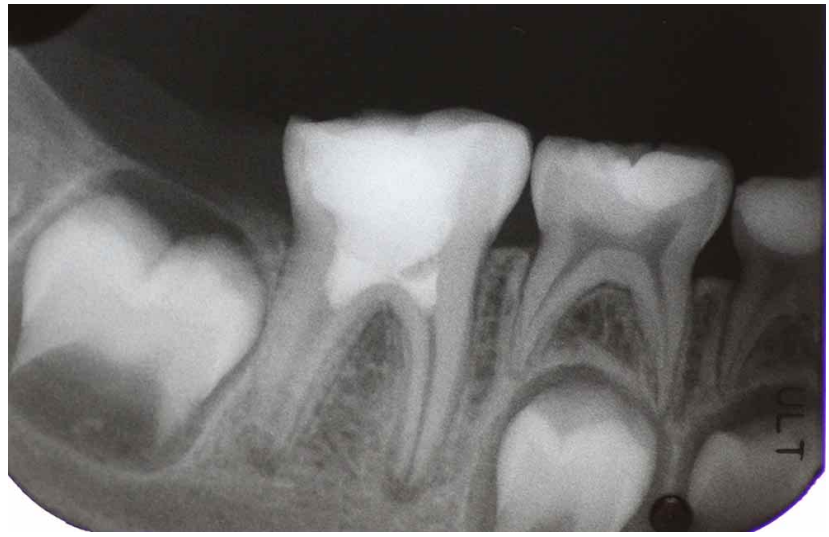

Fig. 8. X-ray at 4 months. The evolution of distal and mesial apical root development is observed.

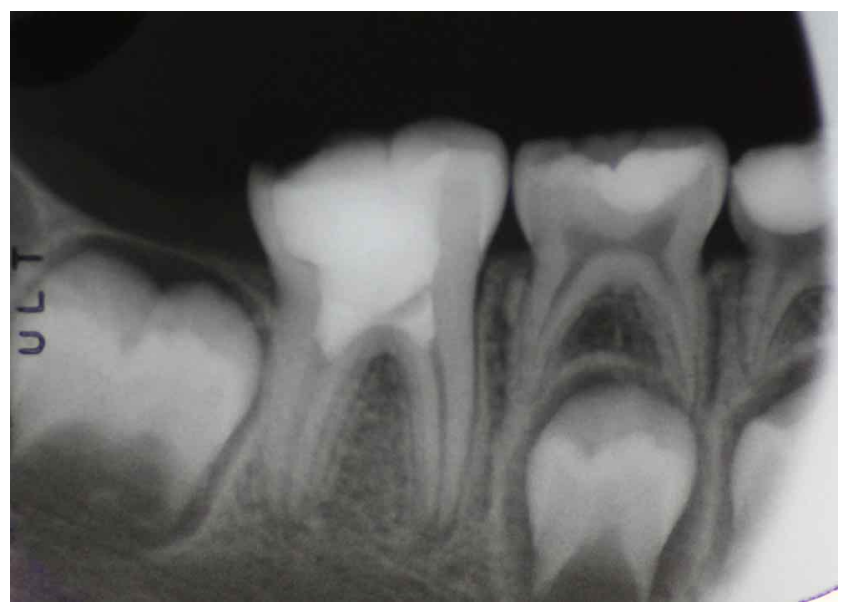

Fig. 9. X-ray control at 7 months.

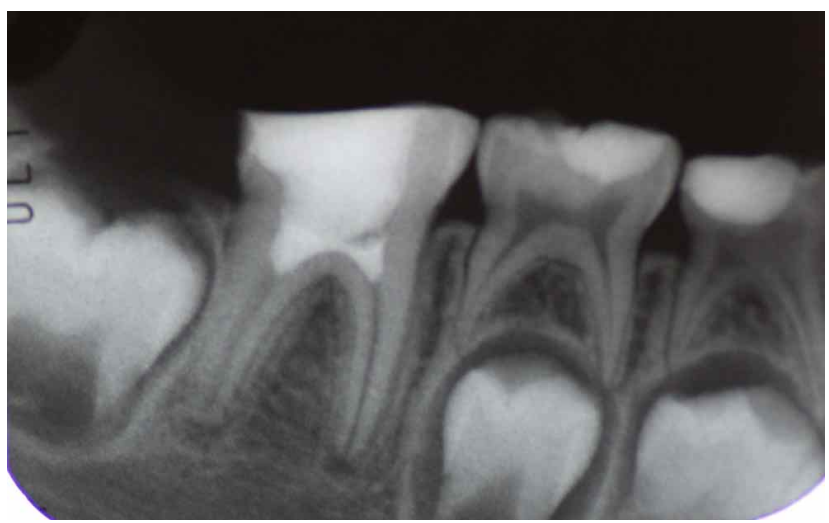

Fig. 10. X-ray at 12 months. Distal root apical closure and mesial root pulp canal narrowing are observed.

\section{RESULTS}

During the control period, tooth 30 was evaluated at 1, 4, 7 and 12 months. The integrity of the restored coronary tissue, marginal gingiva and mucosa of the vestibular fundus were examined, and no clinical alterations were found. There was no painful response to vertical and horizontal percussion tests.

During controls, complementary periapical retroalveolar radiographs were taken to evaluate root development and apical closure. In these it could be observed that there was indeed gradual radicular development of the mesial and distal roots producing apical closure.

\section{DISCUSSION}

Irreversible pulpitis has been defined as the inability of the dental pulp to heal; it is presented as a severe degenerative process. It is commonly treated in immature permanent teeth with pulpectomy and subsequent apexification (Bjørndal, 2008; Levin et al., 2009; Linsuwanont et al., 2017). This procedure has lately been questioned in permanent immature teeth with irreversible pulpitis because of the presence of vitality in the pulp tissue. This challenge has led to investigation of this area in greater depth (Alqaderi et al., 2014).

Although some authors describe the difficulty of establishing objective relationships between the clinical diagnosis of reversible and irreversible pulpitis with histopathology (Seltzer et al., 1963; Barthel et al., 2000), there are others who, based on histological studies, describe that in some teeth with irreversible pulpitis, there are histologically favourable conditions not related to clinical parameters (Ricucci et al., 2014).

The results obtained by Ricucci et al., are concordant with other authors who state that total pulpotomy with MTA application is an option that gives good results in teeth with irreversible pulpitis, maintaining the function and vitality of the tooth (Chueh \& Chiang, 2010).

According to the available evidence, total pulpotomy is a therapy option that seeks to eliminate damaged dental pulp, and tissue possibly contaminated with bacterial microorganisms, favouring a physiological response of the remaining root dental pulp to maintain vitality (Linsuwanont et al.) and thus achieve ideal conditions to stimulate term root development and apical closure in immature teeth (Witherspoon, 2008). It generates a wound in the pulp which activates a complex biological response based on bioactive 
GOMEZ, F.; FUENTES, J.; SARAVIA, D. \& SILVA, M. Induction of root development and apical closure in permanent mandibular molar with irreversible pulpitis through total pulpotomy with application of mineral trioxide aggregate. Int. J. Odontostomat., 14(2):144-149, 2020.

signals, cells and growth factors. In these therapies, it is possible to maintain the root dental pulp which is still vital; this is the ideal path where the cells can move and obtain growth factors, favouring their migration and differentiation for continued development (Clark, 1996; Werner \& Grose, 2003; Barrientos et al., 2008).

The particularity of immature permanent teeth is that they contain the mesenchymal cells of the dental pulp and the dental apical papilla (Albuquerque et al., 2014); these cells have been shown to be stimulated and induced by MTA (Nosrat et al.), achieving in some cases term root development and apical closure of permanent immature teeth with irreversible pulpitis (Qudeimat et al.).

The results of our work is concordant with the reports of other authors (Nosrat et al.; Ricucci et al.; Qudeimat et al.), demonstrating effective stimulation of root development and apical closure in an immature permanent molar with irreversible pulpitis and pulp exposure due to caries. This result was achieved by performing total pulpotomy, MTA application, elimination of contaminated pulp tissue and adequate physiological stimulation for root development and apical closure.

GOMEZ, F.; FUENTES, J.; SARAVIA, D. \& SILVA, M. Inducción del termino de desarrollo radicular y cierre apical en molar mandibular permanente con pulpitis irreversible a través de pulpotomía total con aplicación de agregado de trióxido mineral. Int. J. Odontostomat., 14(2):144-149, 2020.

RESUMEN: La pérdida de vitalidad en dientes con formación radicular incompleta trae como resultado el debilitamiento de estos, dejándolos propensos a fracturas con un desfavorable pronóstico a largo plazo. Las terapéuticas actuales de regeneración pulpar en dientes inmaduros estan principalmente indicadas en cuadros de pulpitis irreversible y buscan eliminar el agente causal de daño y brindarle al diente las condiciones y estímulos necesarios para preservar vitalidad e inducir el cierre apical radicular. Un paciente de 6 años de edad y de sexo masculino, acude a la Clínica de Especialidad de Endodoncia de la Universidad de la Frontera, consultando por un dolor agudo en diente 4.6 el cual presentaba un desarrollo radicular incompleto producto de una caries con exposición pulpar con diagnóstico de Pulpitis Irreversible Sintomática. Se realiza una pulpotomia total con aplicación de Mineral Trioxide Aggregate y se controla a los 1, 4, 6 y 7 meses obteniendo un interesante resultado comparable con estudios que avalan dicha terapeutica en dientes con pulpitis irreversible. Este trabajo busca contribuir a la evidencia existente sobre el manejo de dientes permanentes inmaduros con cuadros de pulpitis irreversible para inducir el desarrollo radicular, cierre apical y mantener vitalidad pulpar.

PALABRAS CLAVE: apexogénesis, pulpotomía, agregado de trióxido mineral.

\section{REFERENCES}

Albuquerque, M. T.; Valera, M. C.; Nakashima, M.; Nör, J. E. \& Bottino, M. C. Tissue-engineering-based strategies for regenerative endodontics. J. Dent. Res., 93(12):1222-31, 2014.

Alqaderi, H. E.; Al-Mutawa, S. A. \& Qudeimat, M. A. MTA pulpotomy as an alternative to root canal treatment in children's permanent teeth in a dental public health setting. J. Dent., 42(11):1390-5, 2014.

American Association of Endodontists. Glossary of Endodontic Terms. $9^{\text {th }}$ ed. Chicago, American Association of Endodontists, 2016. pp.36. Available from: http://www.nxtbook.com/nxtbooks/ aae/endodonticglossary2016

Barrientos, S.; Stojadinovic, O.; Golinko, M. S.; Brem, H. \& TomicCanic, M. Growth factors and cytokines in wound healing. Wound Repair Regen., 16(5):585-601, 2008.

Barthel, C. R.; Rosenkranz, B.; Leuenberg, A. \& Roulet, J. F. Pulp capping of carious exposures: treatment outcome after 5 and 10 years: a retrospective study. J. Endod., 26(9):525-8, 2000.

Bjørndal, L. The caries process and its effect on the pulp: the science is changing and so is our understanding. Pediatr. Dent., 30(3):192-6, 2008.

Camp, J. H. Diagnosis dilemmas in vital pulp therapy: treatment for the toothache is changing, especially in young, immature teeth. Pediatr. Dent., 30(3):197-205, 2008.

Chueh, L. H. \& Chiang, C. P. Histology of Irreversible pulpitis premolars treated with mineral trioxide aggregate pulpotomy. Oper. Dent., 35(3):370-4, 2010.

Clark, R. A. F. The Molecular and Cellular Biology of Wound Healing. $2^{\text {nd }}$ ed. New York, Plenum Press, 1996.

Cvek, M, Prognosis of luxated non-vital maxillary incisors treated with calcium hydroxide and filled with gutta-percha. A retrospective clinical study. Endod. Dent. Traumatol., 8(2):4555, 1992.

Dhillon, H.; Kaushik, M. \& Sharma, R. Regenerative endodontics-Creating new horizons. J. Biomed. Mater. Res. B Appl. Biomater., 104(4):676-85, 2016.

Ghoddusi, J.; Forghani, M. \& Parisay, I. New approaches in vital pulp therapy in permanent teeth. Iran. Endod. J., 9(1):15-22, 2014.

Holland, G.; Trowbridge, H. \& Rafter, M. Protecting the Pulp, Preserving the Apex. In: Torabinejad, M. \& Walton, R. (Eds.). Endodontics, Principles and Practice. $4^{\text {th }}$ ed. St. Louis, Saunders Elsevier, 2008. pp.21-38.

Katebzadeh, N.; Dalton, B. C. \& Trope, M. Strengthening immature teeth during and after apexification. J. Endod., 24(4):256-9, 1998.

Levin, L. G.; Law, A. S.; Holland, G. R.; Abbott, P. V. \& Roda, R. S. Identify and define all diagnostic terms for pulpal health and disease states. J. Endod., 35(12):1645-57, 2009.

Linsuwanont, P.; Wimonsutthikul, K.; Pothimoke, U. \& Santiwong, B. Treatment outcomes of mineral trioxide aggregate pulpotomy in vital permanent teeth with carious pulp exposure: the retrospective study. J. Endod., 43(2):225-30, 2017. 
GOMEZ, F.; FUENTES, J.; SARAVIA, D. \& SILVA, M. Induction of root development and apical closure in permanent mandibular molar with irreversible pulpitis through total pulpotomy with application of mineral trioxide aggregate. Int. J. Odontostomat., 14(2):144-149, 2020.

Nagata, J. Y.; Soares, A. J.; Souza-Filho, F. J.; Zaia, A. A.; Ferraz, C. C.; Almeida, J. F. \& Gomes, B. P. Microbial evaluation of traumatized teeth treated with triple antibiotic paste or calcium hydroxide with $2 \%$ chlorhexidine gel in pulp revascularization. J. Endod., 40(6):778-83, 2014.

Nosrat, A.; Seifi, A. \& Asgary, S. Pulpotomy in caries-exposed immature permanent molars using calcium-enriched mixture cement or mineral trioxide aggregate: a randomized clinical trial. Int. J. Paediatr. Dent., 23(1):56-63, 2013.

Qudeimat, M. A.; Alyahya, A. \& Hasan, A. A. Mineral trioxide aggregate pulpotomy for permanent molars with clinical signs indicative of irreversible pulpitis: a preliminary study. Int. Endod. J., 50(2):126-34, 2017.

Qudeimat, M. A.; Barrieshi-Nusair, K. M. \& Owais, A. I. Calcium hydroxide vs mineral trioxide aggregates for partial pulpotomy of permanent molars with deep caries. Eur. Arch. Paediatr. Dent., 8(2):99-104, 2007.

Rabie, G.; Trope, M. \& Tronstad, L. Strengthening of immature teeth during long-term endodontic therapy. Endod. Dent. Traumatol., 2(1):43-7, 1986.

Ricucci, D.; Loghin, S. \& Siqueira, J. F. Jr. Correlation between clinical and histologic pulp diagnoses. J. Endod., 40(12):19329, 2014.

Robertson, A.; Andreasen, F. M.; Andreasen, J. O. \& Norén, J. G. Long-term prognosis of crown-fractured permanent incisors. The effect of stage of root development and associated luxation injury. Int. J. Paediatr. Dent., 10(3):191-9, 2000.

Seltzer, S.; Bender, I. B. \& Ziontz, M. The dynamics of pulp inflammation: correlations between diagnostic data and actual histologic findings in the pulp. Oral Surg. Oral Med. Oral Pathol., 16:969-77, 1963.

Werner, S. \& Grose, R. Regulation of wound healing by growth factors and cytokines. Physiol. Rev., 83(3):835-70, 2003.

Witherspoon, D. Vital pulp therapy with new materials: new directions and treatment perspectives--permanent teeth. J. Endod., 34(7 Suppl.):S25-8, 2008.
Corresponding author:

Mónica Silva Rodríguez

Dental School

Universidad de La Frontera

Temuco

CHILE

Email: monica.silva@ufrontera.cl

Received: 01-10-2019

Accepted: 18-10-2019 